\title{
Analgesic and Anti-diarrheal Activities of Aganosma dichotoma (Roth) K. Schum. in Swiss-Albino Mice Model
}

\author{
Md. Al Faruk', Mohammad Firoz Khan', Md. Yeunus Mian', Mohammad Sharifur Rahman ${ }^{3}$ \\ and Mohammad A. Rashid ${ }^{3}$ \\ ${ }^{1}$ Department of Pharmacy, Daffodil International University, Dhaka, Bangladesh \\ ${ }^{2}$ Department of Pharmacy, State University of Bangladesh, Dhaka- 1205, Bangladesh \\ ${ }^{3}$ Phytochemical Research Laboratory, Department of Pharmaceutical Chemistry, University of Dhaka, \\ Dhaka- 1000, Bangladesh
}

Received: September 22, 2014; Accepted: November 02, 2014

\begin{abstract}
Aganosma dichotoma (Roth) K. Schum. is an indigenous plant of Bangladesh. Traditional healers use this plant to treat many diseases. In order to systematically explore the medicinal values of this plant, the crude methanol extract of leaves of $A$. dichotoma were screened for analgesic and antidiarrheal activities in mice model. The peripheral and central analgesic actions were determined by using acetic acid-induced writhing and tail immersion methods. The extract significantly $(\mathrm{p}<0.05)$ attenuated the acetic acid-induced writhing in a dose dependent manner. A noticeable dose-dependent increase $(\mathrm{p}<0.05)$ of latency period was also observed in the tail immersion method. In the castor oil induced anti-diarrheal assay, the extract exhibited significant $(\mathrm{p}<0.05)$ anti-diarrheal effect at a dose of $400 \mathrm{mg} / \mathrm{kg}$ body weight.
\end{abstract}

Key words: Aganosma dichotoma, writhing, analgesic, anti-diarrheal

\section{Introduction}

Folk medicines are used in Bangladesh from the time immemorial. In parallel to the modern medicines, traditional medicines are contributing a lot to the national health sector of Bangladesh. Plants are the important sources for screening out the drug candidates. As Bangladesh has numerous plants, proper scientific evaluations are required to explore the potential of these plants for treating various diseases (Banglapedia, 2012a; Ashraf et al., 2014).

Pain is a discomfortable feeling originated from different diseases and injuries. Many types of drugs are available like non-steroidal anti-inflammatory drugs (NSAID), opioids, etc. for pain management. These market products are not completely free from side effects (Su et al., 2012; Yu et al., 2012). However, diarrhea often leads to dehydration and many other complexities. There are some drugs currently used for treating diarrhea but new agents are still required for improved treatment (Li et al., 2013; Zavala-Mendoza et al., 2013). In order to provide patient's safety and comfort regarding pain and diarrhea, plants might serve important sources of medicinal agents.

\section{A. dichotoma (Roth) K. Schum. (Family-} Apocynaceae, Bengali Name- Gandhomalati) is a large climber. Its leaves are 10-12.5 cm long, coriaceous, ovate or elliptic, acute or obtuse. It has a very stout stem and milky latex. The plant is grown all over Bangladesh (Patel et al., 1972; Banglapedia, 2012b). It is used as antiseptic, anthelmintic, psychoactive and emetic. It has also been reported for its free radical scavenging, brine shrimp lethality, antimicrobial and thrombolytic activities (Dey et al., 2014). Previous phytochemical investigations on $A$. dichotoma led to the isolation of quercetin, rutin, kaempferol and phenolic acids (Khare, 2007; Subramanian et al., 2014).

Since this plant has important medicinal properties, the present study has been undertaken as part of our regular research program (Begum et al., 2010; Rahman et al., 2011) and we, herein, report the analgesic and antidiarrheal properties of the leaves of $A$. dichotoma for the first time.

Correspondence to: Mohammad Abdur Rashid; Tel.: 880-2-9661920, Ext. 8137; Fax: 880-2-9667222; E-mail: rashidma@du.ac.bd 


\section{Materials and Methods}

Plant materials: The leaves of $A$. dichotoma were collected in June, 2013 from Sylhet, Bangladesh and a voucher specimen (DACB accession no. 39645) has been deposited in Bangladesh National Herbarium, Mirpur, Dhaka for future reference.

Extraction and fractionation: The collected leaves were sun dried for several days and then oven dried for 24 hours at $40{ }^{\circ} \mathrm{C}$ to facilitate grinding. The powdered leaves $(650 \mathrm{~g})$ of $A$. dichotoma was extracted with $1.8 \mathrm{~L}$ methanol for 7 days and then filtered through a cotton plug followed by Whatman filter paper number 1 . The extract was then concentrated by using a rotary evaporator at reduced temperature $\left(40-45^{\circ} \mathrm{C}\right)$ and pressure. The concentrated methanol extract was used for different biological screenings.

Animals: Swiss albino mice of either sex, weighing 23-25 g, bred in the animal house of Department of Pharmacy, Jahangirnagar University, Savar, Dhaka, Bangladesh were used for the experiments. All the animals were acclimatized for one week prior to the experiments. The animals were housed under standard laboratory conditions (relative humidity 55-65\%, room temperature $25.0 \pm 20{ }^{\circ} \mathrm{C}$, and $12 \mathrm{~h}$ light dark cycle) and fed with standard diet (ICDDRB, B formulated) and had free access to tap water but were fasted $12 \mathrm{~h}$ prior to each experiment. The Federation of European Laboratory Animal Science Associations (FELASA) guidelines and recommendations were followed to reduce the pain and stress of the experimental mice.

Drugs: Drugs and chemicals used in this study include acetic acid solution (1\%), Diclofenac sodium (Square Pharmaceuticals Ltd., Bangladesh), Tramadol (Beximco Pharmaceuticals Ltd., Bangladesh) and Loperamide (Opsonin Pharma Ltd., Bangladesh).

Acetic acid induced writhing: The peripheral analgesic activity of the samples was evaluated in mice using acetic acid induced writhing method (Amabeoku and Kabatende, 2012; Chen et al., 2012; Liao et al., 2012). Mice were divided into 4 groups of 4 mice in each group. The control group received 1\% Tween 80 in normal saline (10 $\mathrm{ml} / \mathrm{kg}$ body weight), the standard group received Diclofenac sodium (50 mg/kg b.w.) and the experimental groups received crude extract of 200 and $400 \mathrm{mg} / \mathrm{kg}$ b.w. Forty minutes later each mouse was injected with $1 \%$ acetic acid at a dose of $10 \mathrm{ml} / \mathrm{kg}$ b.w. The number of writhing responses was recorded for each animal during a subsequent $5 \mathrm{~min}$ period after $10 \mathrm{~min}$ intraperitoneal administration of acetic acid and the mean writhings for each group was obtained.

The percentage inhibition was calculated using the formula -

$\%$ Inhibition $=$

Mean no. of writhing (control) - Mean no. of writhing (drug)

Mean no. of writhing (control) $\times 100$

Tail immersion test: The tail immersion method is a method to evaluate central analgesic activity (Aydin et al., 1999; Kaushik et al., 2012). Again the mice were equally divided into 4 groups. The control group received $1 \%$ Tween 80 in normal saline $(20 \mathrm{ml} / \mathrm{kg}$ b.w. $)$, the standard group received Tramadol $(10 \mathrm{mg} / \mathrm{kg}$ b.w.) and the experimental groups received crude extract of 200 and 400 $\mathrm{mg} / \mathrm{kg} \mathrm{b.w}$. The lower $5 \mathrm{~cm}$ portion of the tail was marked and immersed in warm water $\left(55 \pm 2{ }^{\circ} \mathrm{C}\right)$. Within a few seconds the mice was seen to react by withdrawing the tail and the reaction time was recorded by a stop watch. The experimental reaction time was determined periodically at 0, 30, 60 and 90 minutes after the oral administration of the test substances. The cut-off time for tail immersion latency was set at 15 seconds. The reaction time was also determined prior to the administration of any substances.

Anti-diarrheal activity: Anti-diarrheal activity was evaluated by using castor oil induced method in mice (Agbor et al., 2014; Sebai et al., 2014). Sixteen Swiss albino mice were randomly divided into four groups $(n=4)$. Control group received 1\% Tween 80 in normal saline of $10 \mathrm{ml} / \mathrm{kg}$ of b.w., standard group received Loperamide $50 \mathrm{mg} / \mathrm{kg}$ b.w. as standard drug and the test groups received the extract at the doses of 200 and 400 $\mathrm{mg} / \mathrm{kg}$ b.w. Mice were housed in separate cages with paper lining at the bottom for collection of fecal matters. Diarrhea was induced in the mice by oral administration of castor oil ( $1 \mathrm{ml} /$ mice). Extract and drugs were given orally 1 hour before administration of castor oil. During an observation period of 5 hours, the total number of fecal output by the animals was recorded. Then the percent inhibition of defecation in mice was calculated by using the following equation: 
$\%$ Inhibition $=$

Mean defecation of control - Mean defecation of test sample

Defecation of control

Statistical analysis: The values are presented as mean \pm standard error of mean (SEM) and one way ANOVA analysis was used to determine the significance difference between the control group and experimental groups, the $\mathrm{p}$ values $<0.05$ were considered to be statistically significant.

\section{Result and Discussion}

The methanol extract of $A$. dichotoma was subjected to assay for analgesic and anti-diarrheal activities at a dose of 200 and $400 \mathrm{mg} / \mathrm{kg}$ b.w. In acetic acid induced writhing test, the methanol extract significantly reduced the number of writhing movements induced by the intraperitoneal administration of acetic acid solution. The dose-dependent inhibition (Table 1) of abdominal constrictions by the methanol extract indicates antinociceptive potential of the plant.

Table 1. Effect of methanol extract of $\boldsymbol{A}$. dichotoma on acetic acid induced writhing test.

\begin{tabular}{llcc}
\hline Group & Doses & Number of writhing & \% Inhibition \\
\hline $1 \%$ Tween 80 in normal saline (control) & $10 \mathrm{ml} / \mathrm{kg} \mathrm{b.w.}$ & $8.0 \pm 0.41$ & -- \\
Diclofenac (standard drug) & $50 \mathrm{mg} / \mathrm{kg} \mathrm{b.w.}$ & $3.8 \pm 0.48$ & $53.13 *$ \\
Leaf extract of $A$. dichotoma & $200 \mathrm{mg} / \mathrm{kg} \mathrm{b.w.}$ & $5.0 \pm 0.63$ & 37.50 \\
& $400 \mathrm{mg} / \mathrm{kg}$ b.w. & $4.7 \pm 0.65$ & $41.25 *$ \\
\hline
\end{tabular}

Number of writhing values are (mean $\pm \mathrm{SEM}$ ); $\mathrm{n}=4,{ }^{*} \mathrm{p}<0.05$, indicates significant compared to control.

Prostaglandin is known for pain production. It can be assumed that this plant extract might inhibit either the biosynthetic pathway of prostaglandin production or the binding of prostanoids to their receptors. The extract might also be responsible for inhibiting the production of neuronal mediators (Duarte et al., 1988; Sikder et al., 2013).
The extract of $A$. dichotoma when administered orally at 200 and $400 \mathrm{mg} / \mathrm{kg}$ b.w. exhibited significant analgesic activity in tail immersion method as supported by the increase in latency time when compared to control. The increase in latency period was found to be dose dependant. However, maximum effect was seen at the dose of 400 $\mathrm{mg} / \mathrm{kg}$ b.w. and was comparable with the standard drug (Table 2).

Table 2. Analgesic activity of $\boldsymbol{A}$. dichotoma in tail immersion test.

\begin{tabular}{llcccc}
\hline Groups & Dose & \multicolumn{4}{c}{ Reaction time in seconds at time (min) } \\
\cline { 3 - 6 } & & 0 & 30 & 60 & 90 \\
\hline 1\% Tween 80 in normal saline (control) & $20 \mathrm{ml} / \mathrm{kg}$ b.w. & $5.57 \pm 0.71$ & $4.61 \pm 0.61$ & $3.10 \pm 0.78$ & $1.89 \pm 0.06$ \\
Tramadol (standard drug) & $10 \mathrm{mg} / \mathrm{kg} \mathrm{b.w.}$ & $7.32 \pm 1.24$ & $8.83 \pm 0.17 * *$ & $5.77 \pm 0.15 *$ & $3.27 \pm 0.12$ \\
Leaf extract of $A$. dichotoma & $200 \mathrm{mg} / \mathrm{kg}$ b.w. & $5.02 \pm 1.34$ & $4.59 \pm 0.99$ & $6.70 \pm 0.63 *$ & $2.91 \pm 1.05$ \\
& $400 \mathrm{mg} / \mathrm{kg}$ b.w. & $4.46 \pm 0.8$ & $5.65 \pm 1.94$ & $7.44 \pm 1.31 *$ & $4.25 \pm 1.83$ \\
\hline
\end{tabular}

All values are expressed as mean $\pm \mathrm{SEM} ; \mathrm{n}=4, * \mathrm{p}<0.05, * * \mathrm{p}<0.01$, indicates significant compared to control

Table 3. Anti-diarrheal activity (in terms of \% inhibition) of $\boldsymbol{A}$. dichotoma.

\begin{tabular}{llcc}
\hline Groups & Dose & Number of defecation & Inhibition of diarrhea (\%) \\
\hline 1\% Tween 80 in normal saline (control) & $10 \mathrm{ml} / \mathrm{kg} \mathrm{b.w.}$ & $8.17 \pm 1.73$ & -- \\
Loperamide (standard drug) & $50 \mathrm{mg} / \mathrm{kg} \mathrm{b.w.}$ & $2.67 \pm 0.33$ & $69.23 *$ \\
Leaf extract of $A$. dichotoma & $200 \mathrm{mg} / \mathrm{kg} \mathrm{b.w.}$ & $5.25 \pm 1.03$ & 39.42 \\
& $400 \mathrm{mg} / \mathrm{kg} \mathrm{b.w.}$ & $2.75 \pm 0.48$ & $68.27 *$ \\
\hline
\end{tabular}

All values are expressed as mean $\pm \operatorname{SEM} ; n=4,{ }^{*} \mathrm{p}<0.05$, indicates significant compared to control. 
A delta fibres and $\mathrm{C}$ fibres sensory neurons in skin are linked for thermal pain generation. Besides, ion channels in the skin also respond to temperature. The tested effective analgesic plant in the tail immersion assay might have the ability to modulate the action potential and signal transmission to counteract the pain produced by heat (Harris and Ryall, 1988).

In the castor oil-induced diarrheal experiment, the extract of $A$. dichotoma produced a marked anti-diarrheal effect in mice, as shown in Table 3. The increase in antidiarrheal activity was dose dependant at doses of 200 and $400 \mathrm{mg} / \mathrm{kg}$ body weight but significant anti-diarrheal effect was observed at a dose of $400 \mathrm{mg} / \mathrm{kg}$ body weight as compared to the control group. This plant is rich in flavonoids (Subramanian et al., 2014) and this type of secondary metabolites were proved to be very effective to manage diarrhea (Yao et al., 2011).

\section{Conclusion}

The leaf extract of $A$. dichotoma was found to be very effective in pain and diarrhea management. Further extensive studies are required to isolate the bioactive compounds and to explore the underlying mechanisms for these bioactivities.

\section{References}

Agbor, G.A., Longo, F., Makong, E.A. and Tarkang, P.A. 2014. Evaluation of the antidiarrheal and antioxidant properties of Justicia hypocrateriformis. Pharm. biol. 52, 11281133.

Amabeoku, G.J. and Kabatende, J. 2012. Antinociceptive and anti-inflammatory activities of leaf methanol extract of Cotyledon orbiculata L. (Crassulaceae). Adv. Pharmacol. Sci. 2012, 862625.

Ashraf, M.A., Khatun, A., Sharmin, T., Mobin, F., Tanu, A.R., Morshed, T., Fakir, T.A., Begum, R.A. and Nabi, A.N. 2014. MPDB 1.0: a medicinal plant database of Bangladesh. Bioinformation 10, 384-386.

Aydin, S., Demir, T., Ozturk, Y. and Baser, K.H. 1999. Analgesic activity of Nepeta italica L. Phytother. Res. 13, 20-23.

Banglapedia. 2012a. Garden Flowers. National Encyclopedia of Bangladesh (online edition). http://www.banglapedia.org/ HT/G_0040.htm, ISBN-978-984-512-021-970...978-984512-048-977.
Banglapedia. 2012b. Healthcare System. National Encyclopedia of Bangladesh (online edition); http://www. banglapedia.org/HT/H_0132.htm; ISBN-978-984-512021-970 ... 978-984-512-048-977.

Begum, R., Rahman, M.S., Chowdhury, S., Rahman, M.M., Gibbons, S. and Rashid, M.A. 2010. A new 7-oxygenated coumarin from Clausena suffruticosa. Fitoterapia 81, 656-658.

Chen, J., Wang, X., Qu, Y.G., Chen, Z.P., Cai, H., Liu, X., Xu, F., Lu, T.L. and Cai, B.C. 2012. Analgesic and antiinflammatory activity and pharmacokinetics of alkaloids from seeds of Strychnos nux-vomica after transdermal administration: effect of changes in alkaloid composition. J. Ethnopharmacol. 139, 181-188.

Dey, S.C., Khan, M.F., Rahman, M.S. and Rashid, M.A. 2014. Preliminary free radical scavenging, brine shrimp lethality, antimicrobial and thrombolytic activities of Aganosma dichotoma (Roth) K. Schum. Bang. Pharm. J. 17, 177-181.

Duarte, I.D., Nakamura, M. and Ferreira, S.H. 1988. Participation of the sympathetic system in acetic acidinduced writhing in mice. Braz. J. Med. Biol. Res. 21, 341-343.

Harris, N.C. and Ryall, R.W. 1988. Mustard oil excites but does not inhibit nociceptive dorsal horn neurones in the rat: a presumed effect on A-delta fibres. Br. J. Pharmacol. 94, 180-184.

Kaushik, D., Kumar, A., Kaushik, P. and Rana, A.C. 2012. Analgesic and Anti-Inflammatory Activity of Pinus roxburghii Sarg. Adv. Pharmacol. Sci. 2012, 245431.

Khare, C.P. 2007. Indian Medicinal Plants: An Illustrated Dictionary. Springer Science, LLC, NY, USA. p. 24.

Li, J., Wu, X.L., Chen, Y., Tang, Z., Xu, Y.H., Jiang, J.M., Gu, Y.Y., Chen, J.P., Yang, D.P. and Wang, D.M. 2013. Antidiarrheal properties of different extracts of Chinese herbal medicine formula Bao-Xie-Ning. J. Integr. Med. 11, 125-134.

Liao, C.R., Chang, Y.S., Peng, W.H., Lai, S.C. and Ho, Y.L. 2012. Analgesic and anti-inflammatory activities of the methanol extract of Elaeagnus oldhamii Maxim. in mice. Am. J. Chin. Med. 40, 581-597.

Patel, J.D., Kothari, I.L. and Pathan, M.A. 1972. Stomatal Features in the Leaf of Aganosma dichotoma (Roth) K. Schum. Ann. Bot. 36, 849-856.

Rahman, M.S., Rahman, M.Z., Begum, B., Chowdhury, R., Islam, S.N. and Rashid, M.A. 2011. Antidiabetic principle from Eclipta prostrata. Latin Am. J. Pharm. 30, 1656-1660. 
Sebai, H., Jabri, M.A., Souli, A., Rtibi, K., Selmi, S., Tebourbi, O., El-Benna, J. and Sakly, M. 2014. Antidiarrheal and antioxidant activities of chamomile (Matricaria recutita L.) decoction extract in rats. J. Ethnopharmacol. 152, 327-332.

Sikder, M.A., Rashid, R.B., Islam, F., Hossian, A.K.M.N., Siddique, A.B., Kabir, S., Haque, M.R., Rahman, M.S. and Rashid, M.A. 2013. Screening of ten medicinal plants of Bangladesh for analgesic activity on Swissalbino mice. Orient. Pharm. Exp. Med. 13, 327-332.

Su, S., Hua, Y., Wang, Y., Gu, W., Zhou, W., Duan, J.A., Jiang, H., Chen, T. and Tang, Y. 2012. Evaluation of the antiinflammatory and analgesic properties of individual and combined extracts from Commiphora myrrha and Boswellia carterii. J. Ethnopharmacol. 139, 649-656.

Subramanian, G., Meyyanathan, S.N., Karthik, Y., Karunakaranair, A. and Palanisamy, D.S. 2014. Development and validation of HPLC method for the simultaneous estimation of quercetin and rutin in Aganosma dichotoma (Roth) K. Schum. Int. J. Pharm. Sci. 6, 606-608.
Yao, W.R., Wang, H.Y., Wang, S.T., Sun, S.L., Zhou, J. and Luan, Y.Y. 2011. Assessment of the antibacterial activity and the antidiarrheal function of flavonoids from bayberry fruit. J. Agric. Food Chem. 59, 5312-5317.

Yu, C.H., Tang, W.Z., Peng, C., Sun, T., Liu, B., Li, M., Xie, X.F. and Zhang, H. 2012. Diuretic, anti-inflammatory and analgesic activities of the ethanol extract from Cynoglossum lanceolatum. J. Ethnopharmacol. 139, 149154.

Zavala-Mendoza, D., Alarcon-Aguilar, F.J., Perez-Gutierrez, S., Escobar-Villanueva, M.C. and Zavala-Sanchez, M.A. 2013. Composition and antidiarrheal activity of Bidens odorata Cav. Evid. Based Complement. Alternat. Med. 2013, 170290. 